\title{
Evaluation of Factors Contributing towards the Adoption of Islamic Banking: Evidence from Lahore, Punjab, Pakistan
}

\author{
Hamayun Afzal ${ }^{1}$, Muhammad Ali Jibran Qamar', Adeel Ahmad \\ ${ }^{1}$ Department of Management Sciences, Bahauddin Zakariya University, Multan \\ ${ }^{2}$ Department of Management Sciences, COMSATS Institute of Information Technology, Lahore, \\ ${ }^{3}$ Department of Management Sciences, National University of Sciences E Technology, Islamabad
}

\begin{abstract}
Since the introduction of Islamic Banking in the international financial paradigm extensive research has been under attention with the purpose of identifying the factors that influence the adoption of Islamic banking. With the objective of identifying the factors that influence the selection of Islamic Banking in Pakistan, this study investigates the impact that factors like attitude, social and religious influence, governmental support and pricing have in deciding whether to go for conventional banking or Islamic banking. The sample comprised of 250 respondents and collected from customers of Islamic banks by using a structured questionnaire. The study used SPSS to analyze the data using reliability analysis, factor analysis, descriptive analysis, and correlation and regression analysis. The results suggest that attitude, social and religious influence and government support to be significant factors in inclining a customer towards Islamic banking.
\end{abstract}

\section{Introduction}

Banking activities are important for the economic stability and growth of any country. Banking gained prominence soon after the Industrial Revolution during the 18th century. The banks are the institutes which accept deposits from the people who have surplus and then use these deposits to provide funds to the businesses and entrepreneurs who desire funds for growing their businesses or to meet their financial requirements. These banks perform the role of intermediary between those who have excess of funds and the ones who have shortage of funds. This results in greater usage of funds and thus leads towards greater and prosperous economies.

The push towards a banking system founded on the Islamic principles was stimulated by failures of the conventional financial system (Chapra, 2008). It was due to this failure of the conventional financial system that the economies all over have faced over 100 crises in the recent few decades (Stiglitz, 2003). Chapra (2008) suggests that one of the most vital causes behind these crises was the excessive and imprudent lending by banks to earn higher profits as an interest in lieu of these lending activities. This meant that unless an interest free system was introduced the economies would have continued to experience recurring crises.

Islamic banking finds its roots in Shariah Law, which prohibits interest in all forms as it is of the view that interest leads towards undue exploitation of those in need and ultimately results in unequal wealth distribution (Khan \& Asghar, 2012). Islamic banks are working with the sole objective of offering riba free alternatives of the conventional banking offerings (Jamshidi and Hussin, 2012). The system of Islamic banking is based on the guidelines and principles of Shariah while on other hand the system of conventional banking is based on the man-made principles of interest. Islamic banks work on the tune of profit-loss sharing while the conventional banks are only interested in earning profits while imposing all possibilities of risk to the borrower.

\section{Research gap}

Banking industry experienced phenomenal growth during $21^{\text {st }}$ century, this came with the amalgamation of threats and opportunities as new horizons like Islamic Banking emerged during this time. This emergence of Islamic banking created competition in the conventional banking. This study was undertaken with the realization that with the emergence of Islamic banking as alternative to the global banking system there is a need to assess the benefits of the Islamic banking with special concentration on the Pakistani banking

Corresponding Author: Hamayun Afzal, e-mail: hamayunkhichi@hotmail.com

COMSATS Institute of Information Technology Lahore, Pakistan. 
industry. The study attempts to identify the factors that dictate the intent to use Islamic banking and thus tries to identify the ways through which greater financial inclusion can be achieved through the utilization of Islamic banking medium.

\section{Significance of the study}

Though relatively new segment, Islamic banking went under swift development during the past three decades. Islamic banking is important to identify factors that influence the adoption of Islamic banking. One needs to enter a value for the most realistic works of literature in Islamic banking functions. This will allow the governments to ensure greater financial inclusion thus not only supporting the poverty alleviation but also helping with greater mobility in terms of currency management. This research can help policy makers to explore the attitude, social impact and religious influence of people on the intention to use Islamic banking in Pakistan and will identify the areas that need attention to bring the masses under the structured financial system of the country.

\section{Research Questions}

1. Is there any relationship between an individual's attitude and his decision to opt for Islamic Banking? If yes then of what kind?

2. Is there any relationship between social influence and decision to opt Islamic Banking? If yes then of what kind?

3. Is there any relationship between religious influence and decision to opt Islamic Banking? If yes then of what kind?

4. Is there any relationship between the government support and the decision to opt Islamic Banking? If yes then of what kind?

\section{Literature Review}

"Islamic Banking" can be defined as the system in which banking operations and banking services are carried out within the limits defined in Islam (Mirakhor, 2000). The primary standards of Islamic banking are the exclusion of interest in all types of transactions and exchanges (Mirakhor, 2000). Haq et al., (2007) is of the view that dissimilar to conventional mode of banking, the Islamic variant is founded on exclusion of interest in all forms and for every type of transaction involved. In the way of recent decades, Islamic banking has proven to be the speediest rising industries, at an expected development rate of 15-20\% for every year (Tara et al., 2014). It has been adopted by different economies all over the world, thus receiving acknowledgement from Muslims and non-Muslims equally (Aziz, 2006). Interesting attention is provided by the government of Malaysia, it has shown keen interest in developing an optimized framework for carrying out banking transactions as per the Islamic teachings (Thambiah et al, 2010).

Islamic banking is based on the basic foundation to carry out interest-free activities based on Shariah principles. The most important feature of Islamic banking is the sharing of profit-loss with participants of banking system and conducting all activities including borrowing and lending without interest (Al-Jarhi \& Iqbal, 2001). Islamic banking success forced other banks to offer products to their clients based on Islamic banking (Iqbal al, 1998). Two rivers, the Islamic banks and conventional banks, Islamic banks exist some questions and poses major challenges in the mind of customers in acceptance of Islamic banking in Pakistan (Najajmabadi, 1991).

With objective of identifying the factors that influence the customers selection of Islamic Banking in Lahore, Pakistan, this study investigates the impact that factors like attitude, relative advantage, compatability, ease of use, social and religious influence, governmental support and pricing in deciding whether to select conventional banking or Islamic banking. The researcher investigated the positive relationship between attitude and the intention to use Islamic banking (Schiff man and Kanuk 2004, Jamshidi and Hussin 2012). On the same foundations, some studies also investigated the positive relationship between social influence and the intention to use Islamic banking (Taib et al. 2008, Khurram and Saeed, 2015). Some studies also investigated the positive relationship between religious influence and government support and intention to use Islamic banking (Amin et al., 2011, Ouafy, \& Chakir 2015). Some studies also investigated the relationship between pricing and the intention to use Islamic banking (Hanudin et al., 2011). 


\subsection{Theory of Reasoned Action}

This theory was presented by Fishbein and Ajzen in 1975 with the objective of achieving the end goal of building up connections between convictions, mentalities, aims and practices (Taib et al., 2008). The present study covers the hypothesis to Islamic individual finance setting. Two special factors of TRA, in particular, state of mind and subjective standard are connected in the current study subsequent to past studies showed that acknowledgment of Islamic finance can be clarified by the factors of TRA (Amin et al., 2011; Taib et al., 2008).

\subsection{Attitude}

Jamshidi and Hussin (2012) referred to Fishben and Ajzen who consider state of mind as an evaluative impact which is a result of an individual's hopeful and negative sentiments following in a specific conduct. Attitude when defined in the context of consumer behavior is the tendency to behave in a definite manner when confronted with the same scenario (Schiff man and Kanuk, 2004). There are various studies relating attitude to conduct. Utilizing the study strategy, Gopi and Ramayah (2007) analyzed Master of Business Administration's understudies' goal to utilize versatile PCs and observed it to be essentially identified by state of mind.

\subsection{Relative advantage}

The relative favorable position is characterized as the amount to which a progress is seen as being greater to the "thought" it succeeds. Rogers (2003) found that adopters constantly saw the relative favorable position regarding the financial advantages, monetary advantages and the expenses coming about because of the selection of advancement and upgrades that are standing to their economic wellbeing. The positive impact of relative point of preference on people's goal to embrace Internet keeping money has been found in a few past studies (Ajam, and Nor, 2013).

\subsection{Ease of Use}

The researcher investigated relationship between the ease of use and intention to use Islamic Banking. It is undifferentiated from the "ease of use" developments in non-Islamic keeping money. In this exploration, the expression "usability" is utilized rather than "multifaceted nature". Demeanors are likewise influenced by seeing convenience. Seen usability finds with the degree to which people trust that using a specific structure would require no effort (Nasri, 2011). Seen usability was found to impact the reception of Internet keeping money administration. When a framework is observed and seen as simple or easy clients will have the expectation to utilize the framework (Ajam and Nor, 2013).

\subsection{Compatibility}

Rogers (2003) defines compatibility of any new concept, invention or innovation in perspective of measuring it with the perspective of its consistency or alignment with the past experiences, current values and the needs of potential adopters. Therefore it is actually the alignment of an individual's values and beliefs with the product on offer (Gerard, 2003). The study led by Tan and Teo (2000), the apparent similarity of a development was found to impact the reception of the said advancement. At the end of the day, clients will just embrace emanaging an account developments that in their perspective are good with their qualities about living and working.

\subsection{Social Influence}

Social influence alludes to subjective standard or standardizing weight. Taib et al. (2008) suggest that subjective standard was perceived to be a more persuasive indicator of expectation to use Islamic finance than a state of mind. Notwithstanding, the consequences of past studies have been blended. Xihao and Yang (2004) state that influence of friends, associates and family play as important role in shaping decision of consumer regarding whether to buy a certain product or not. For example, in the setting of food purchasing behavior, Bonne et al., (2007) led an empirical study in France to find the factors influencing Halal meat consumption within 576 Muslim migrants. Social influence was studied in relation to Muslim self-identity as a moderating variable between attitude, subjective norm and intention. Findings suggested that customer claims to be influenced by family, friends and religious organizations and that predict positive relationship between subjective norm and purchase of Halal meat. 


\subsection{Religious Influence}

Religion is defined as "a system of beliefs and practices through which a group of people interpret and react, compared to what they regard it as mystical and spiritual". Furthermore, religion is a social institution that shapes and controls the beliefs and behaviors of people (Johnston, 1975). Religion influences individual behavior, taking into account two aspects: the first is the principles, rules and obligations that organize individual behavior, and sanctions that control. The second aspect deals with religion as a powerful social institution with a remarkable role in culture and social values development (Ouafy, \& Chakir, 2015). According to Metawa \& Almossawi (1998) found religion to be the most significant element in influencing Muslim customer's decisions to adopt Islamic Banking. Tara et al., (2014) presented religion as a psychological connection and a prominent emotional relationship to things.

\subsection{Government Support}

It refers to decisions that affect the citizens in making them to adopt the introduced system. The government actions and objectives that influence an individual's behavior are referred to as government support. Amin et al., (2011) findings suggest that Islamic banking products and government support are positive and significantly associated with each other. For example, before 1993, a pioneer in the Malaysian government, safe before allowing Islamic banking industry to establish an Islamic bank for ten years. Government support plays a vital role for Islamic banks to emerge with the new concept of banking due to high market competition (Hanudin et al., 2011).

\subsection{Pricing}

Pricing plays an important part in building consumers' perception further this perception leads towards a decision whether to buy a product on offer or not at the given price. In case of Islamic banks prices of Islamic personal financing are set keeping in view the need to establish a stability between the interest of the bank and its customers. Profit and Loss sharing mechanism are adopted by Islamic banks in this regard (Olson and Zoubi, 2008). Pricing is an important factor in determining the objective of people to Islamic personal financing as seen in Malaysia (Amin and Rahim, 2009).

\section{Research Hypothesis}

Hypothesis 1: Attitude affects the intent to use Islamic Banking.

Hypothesis 2: $\quad$ Social influence affects the intent to use Islamic Banking.

Hypothesis 3: $\quad$ Religious influence affects the intent to use Islamic Banking.

Hypothesis 4: Government support affects the intent to use Islamic Banking.

Hypothesis 5: Price plays a moderating role between attitude and intent to use Islamic banking.

Hypothesis 6: Price plays a moderating role between social influence and the intent to use Islamic Banking.

Hypothesis 7: $\quad$ Price plays a moderating role between religious influence and the intent to use Islamic Banking.

Hypothesis 8: Price plays a moderating role between government support and the intent to use Islamic Banking.

\section{Methodology}

In this research, primary data will be used to do analysis, interpret and elaborate. We were using 250 samples out of the whole population which is based on the population and sample size. The respondents were contacted in person by going to different branches of the different Islamic banks of Lahore and by distributing questionnaires for data collection. The questionnaires were also distributed among faculty members and students of university for getting good response. The questionnaires is separated into two parts. The part 1 is asking the demographic questions about the respondents and in the part 2 questions are designed are which related to our independent variables and the dependent variable. The Likert's 5-point scale is the most suitable to estimate the range. The scale $1-5$ represents strongly agree and as strongly disagree. SPSS software is used for the statistical analysis of the data and hypothesis testing. 


\section{Conceptual Framework}

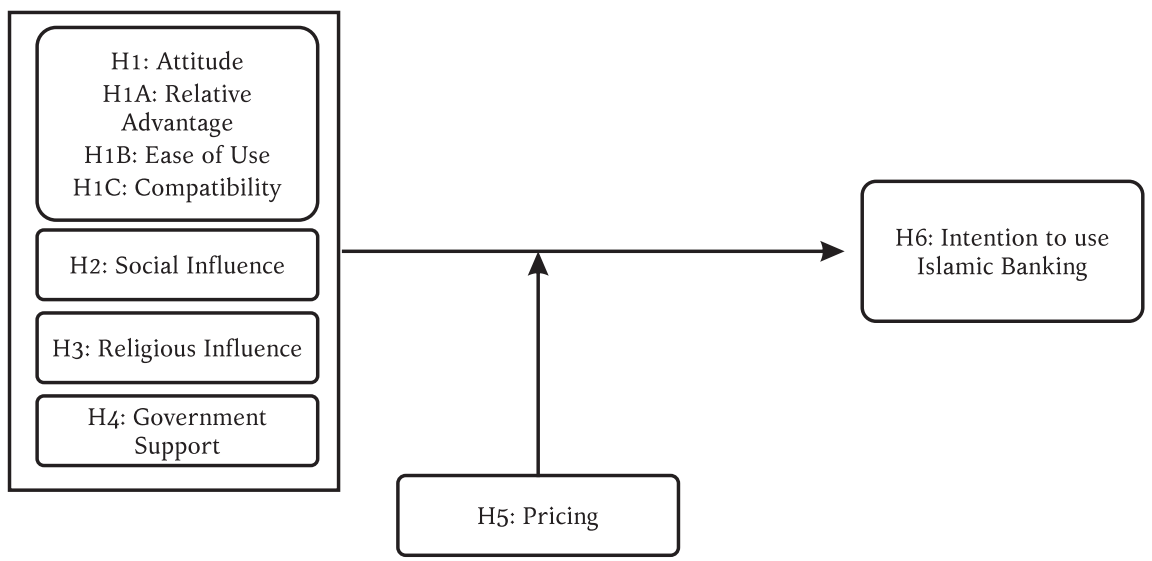

\section{Statistical Model}

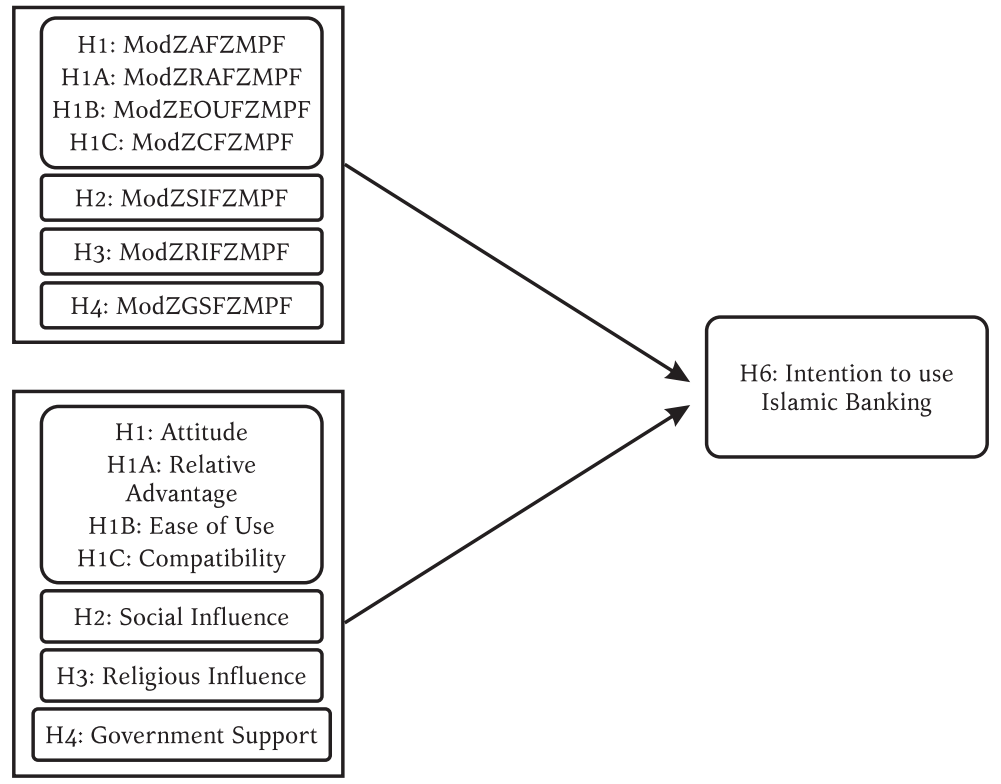


COMSATS Journal of Islamic Finance

8. Statistical Analysis

Statistical analysis is performed with the help of SPSS Software which is designed for this purpose.

Table 1 - Reliability Analysis

\begin{tabular}{clcc}
\hline & Item & Cronbach's Alpha & Total Items \\
\hline 1 & Measuring Price & .827 & 5 \\
\hline 2 & Intention to Use IB & .887 & 5 \\
\hline 3 & Relative Advantage & .743 & 5 \\
\hline 4 & Ease of Use & .617 & 5 \\
\hline 5 & Compatibility & .865 & 5 \\
\hline 6 & Attitude & .907 & 6 \\
\hline 7 & Social Influence & .859 & 5 \\
\hline 8 & Religious Influence & .865 & 5 \\
\hline 9 & Government Support & .773 & 4 \\
\hline 10 & Total & .941 & 45 \\
\hline
\end{tabular}

Table 1 shows the reliability of the test. As our results are 0.941 higher than the required level of 0.7 therefore this suggests that the adopted scale is reliable and consistent.

Descriptive Analysis:

Table 2 - Gender of the Respondents

\begin{tabular}{cccccc}
\hline & & Frequency & Percent & Valid Percent & Cumulative Percent \\
\hline \multirow{3}{*}{ Valid } & Male & 179 & 71.6 & 71.6 & 71.6 \\
\cline { 2 - 6 } & Female & 71 & 28.4 & 28.4 & 100.0 \\
\cline { 2 - 6 } & Total & 250 & 100.0 & 100.0 & \\
\hline
\end{tabular}

Table 2 shows the descriptive statistics of control variable gender which shows that the male participated in the survey were 179 of the total sample size which is 250 . Similarly the female participated in the survey were 71 of the total sample. It means that the majority of the respondents were males participated in the study.

Table 3 - Marital Status of the Respondents

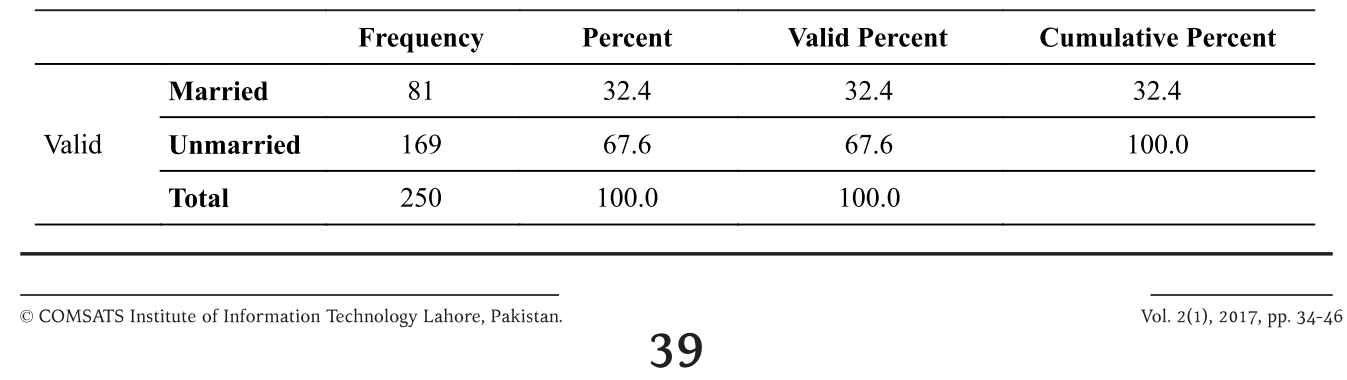


Afzal et al

Table 3 shows the descriptive statistics of control variable marital status which shows that the married participated in the survey were 81 of the total sample size 250 . Similarly the unmarried people who participated in the survey were 169 of the total sample. It means that the majority of the respondents who participated in the study were unmarried.

Table 4 - Age of the Respondents

\begin{tabular}{llcccc}
\hline & Frequency & Percent & Valid Percent & Cumulative Percent \\
\hline \multirow{4}{*}{ Valid } & $\mathbf{2 0 - 2 9}$ & 52 & 71.2 & 71.2 & 71.2 \\
\cline { 2 - 6 } & $\mathbf{3 0 - 3 9}$ & 20.8 & 20.8 & 92.0 \\
\cline { 2 - 6 } & $\mathbf{4 0 - 4 9}$ & 5 & 5.6 & 5.6 & 97.6 \\
\cline { 2 - 6 } & $\mathbf{5 0}$ and Above & 6.4 & 2.4 & 100.0 \\
\cline { 2 - 6 } & Total & 250 & 100.0 & 100.0 & \\
\hline
\end{tabular}

Table 4 shows the descriptive statistics of control variable age which shows that the 178 respondents were age group range 20-29, 52 respondents were age group range 30-39, and 14 respondents were age group range 4049 , and 6 respondents were age group range $50 \&$ above. These statistics shows that the majority of the respondents were young who participated in this study.

Table 5 - Educational Level of the Respondents

\begin{tabular}{llcccc}
\hline & & Frequency & Percent & Valid Percent & Cumulative Percent \\
\hline \multirow{5}{*}{ Valid } & Matric & 4 & 1.6 & 1.6 & 1.6 \\
\cline { 2 - 6 } & FA & 20 & 8.0 & 8.0 & 9.6 \\
\cline { 2 - 6 } & Graduate & 72 & 28.8 & 28.8 & 38.4 \\
\cline { 2 - 6 } & Master & 103 & 41.2 & 41.2 & 79.6 \\
\cline { 2 - 6 } & MS/M.Phil & 44 & 17.6 & 17.6 & 97.2 \\
\cline { 2 - 6 } & & 7 & 2.8 & 2.8 & 100.0 \\
\hline
\end{tabular}

Table 5 shows the descriptive statistics of control variable educational level which shows that the 4 respondents were matric degree holder, 20 respondents were FA degree holder, 72 respondents were graduate degree holder, 103 respondents were master degree holder, 44 respondents were MS/M.Phil degree holder, and 7 respondents were $\mathrm{PhD}$ degree holder. These statistics show that the majority of the respondents were master degree holders who participated in this study.

Regression Analysis

\begin{tabular}{c|c|c|c|c|c}
\hline \multicolumn{6}{c}{ Table 6 - Model Summary } \\
\hline Model & $\mathrm{R}$ & R Square & Adjusted R Square & Std. Error of the Estimate & Durbin-Watson \\
\hline 1 & $.823^{\mathrm{a}}$ & .678 & .668 & .54637 & 2.065 \\
\hline
\end{tabular}

a. Predictors: (Constant), GSF, RAF, RIF, EOUF, SIF, CF, AF

b. Dependent Variable: ITUF

c) COMSATS Institute of Information Technology Lahore, Pakistan. 


\section{COMSATS Journal of Islamic Finance}

Table 6 shows model summary in which Durbin-Watson statistic for this analysis is 2.065 so it can be accepted that there is independence of errors or no auto correlation. The "R" value of 0.823 shows a good level of prediction. The "R Square" shows the value of 0.678 that independent variables explain $67.8 \%$ of the variability of our dependent variable. Adj. R2 is 0.668 (66.8\%), which indicate the large effect size.

Table 7 - ANOVA

\begin{tabular}{llccccc}
\hline \multicolumn{1}{l}{ Model } & Sum of Squares & Df & Mean Square & F & Sig. \\
\hline \multirow{2}{*}{1} & 151.977 & 7 & 21.711 & 72.728 & $.000^{\mathrm{b}}$ \\
\cline { 2 - 6 } & Regression & 72.242 & 242 & .299 & & \\
\cline { 2 - 6 } & Residual & 224.219 & 249 & & & \\
\hline
\end{tabular}

a. Dependent Variable: ITUF

b. Predictors: (Constant), GSF, RAF, RIF, EOUF, SIF, CF, AF

Table 7 shows the F-ratio in the ANOVA. The F-ratio is $(7,242)=72.728$ and the significant value is 0.000 so our model is significant and fit for data.

\section{Correlation Analysis}

Table 8 - Pearson Correlation

\begin{tabular}{lllllllll|}
\hline & ITUF & RAF & EOUF & CF & AF & SIF & RIF & GSF \\
ITUF & 1.000 & & & & & & & \\
RAF & $.512^{*}$ & 1.000 & & & & & & \\
EOUF & $.457^{*}$ & $.622^{*}$ & 1.000 & & & & & \\
CF & $.726^{*}$ & $.590^{*}$ & $.503^{*}$ & 1.000 & & & & \\
AF & $.788^{*}$ & $.564^{*}$ & $.452^{*}$ & $.785^{*}$ & 1.000 & & & \\
SIF & $.676^{*}$ & $.545^{*}$ & $.492^{*}$ & $.658^{*}$ & $.744^{*}$ & 1.000 & & \\
RIF & $.657^{*}$ & $.535^{*}$ & $.424^{*}$ & $.713^{*}$ & $.681^{*}$ & $.617^{*}$ & 1.000 & \\
GSF & $.311^{*}$ & $.305^{*}$ & $.305^{*}$ & $.367^{*}$ & $.431^{*}$ & $.445^{*}$ & $.376^{*}$ & 1.000 \\
\hline
\end{tabular}

Level of significant is $1 \%$

Table 8 shows the relationship between two variables e.g Correlation between intension to use and relative advantage is 0.512 which is greater than 0.5 which shows strong correlation between two variables. Correlation between intension to use and ease of use is 0.457 which is less than 0.5 which shows week correlation between two variables. Correlation between intension to use and compatibility is 0.726 which is strong. Correlation between intension to use and attitude is 0.788 which is strong. Correlation between intension to use and social influence is 0.676 which is strong. Correlation between intension to use and religious influence is 0.657 which is strong. Correlation between intension to use and government support is 0.311 which is weak. We can see from the Correlations table that the variables are strongly related. 
Afzal et al

Table 1 - Reliability Analysis

\begin{tabular}{|c|c|c|c|c|c|c|c|}
\hline \multirow[t]{2}{*}{ Model } & \multicolumn{2}{|c|}{ Unstandardized Coefficients } & \multirow{2}{*}{$\frac{\text { Standardized Coefficients }}{\text { Beta }}$} & \multirow[t]{2}{*}{$\mathrm{T}$} & \multirow[t]{2}{*}{ Sig. } & \multicolumn{2}{|c|}{ Collinearity Statistics } \\
\hline & B & Std. Error & & & & Tolerance & VIF \\
\hline (Constant) & -.017 & .160 & & -.106 & .916 & & \\
\hline RAF & -.032 & .066 & -.026 & -.487 & .626 & .484 & 2.068 \\
\hline EOUF & .094 & .067 & .068 & 1.408 & .160 & .566 & 1.767 \\
\hline $\mathrm{CF}$ & .186 & .070 & .175 & 2.641 & .009 & .303 & 3.301 \\
\hline $\mathrm{AF}$ & .490 & .073 & .467 & 6.752 & .000 & .278 & 3.598 \\
\hline SIF & .159 & .065 & .144 & 2.460 & .015 & .387 & 2.584 \\
\hline RIF & .147 & .058 & .142 & 2.548 & .011 & .430 & 2.324 \\
\hline GSF & -.101 & .049 & -.085 & 2.042 & .042 & .769 & 1.301 \\
\hline
\end{tabular}

This table 9 shows that the significant value of compatibility, attitude, social influence, religious influence and government support is less than 0.05 which shows that these variables are significant. In this data, the Tolerance values are greater than 0.1 (the lowest is 0.278 ), so there is no collinearity problem in this particular data.

\begin{tabular}{|l|l|c|}
\hline Hypothesis 1 & Attitude affects the intent to use Islamic Banking. & Accepted \\
\hline Hypothesis 2 & Social influence affects the intent to use Islamic Banking. & Accepted \\
\hline Hypothesis 3 & Religious influence affects the intent use Islamic Banking. & Accepted \\
\hline Hypothesis 4 & Government support affects the intent to use Islamic Banking. & Rejected \\
\hline
\end{tabular}

Moderation

A moderator variable is a third variable which affects the strength of the relationship between a dependent and independent variable. Pricing is moderating variable in this study.

Regression Analysis

Table 10 - Model Summary

\begin{tabular}{|c|c|c|c|c|c|c|c|c|c|c|}
\hline \multirow[t]{2}{*}{ Model } & \multirow[t]{2}{*}{$\mathrm{R}$} & \multirow{2}{*}{$\begin{array}{c}\mathrm{R} \\
\text { Square }\end{array}$} & \multirow{2}{*}{$\begin{array}{l}\text { Adjusted R } \\
\text { Square }\end{array}$} & \multirow{2}{*}{$\begin{array}{l}\text { Std. Error of } \\
\text { the Estimate }\end{array}$} & \multicolumn{5}{|c|}{ Change Statistics } & \multirow{2}{*}{$\begin{array}{l}\text { Durbin - } \\
\text { Watson }\end{array}$} \\
\hline & & & & & $\begin{array}{l}\text { R Square } \\
\text { Change }\end{array}$ & $\begin{array}{c}\mathrm{F} \\
\text { Change }\end{array}$ & df 1 & df2 & $\begin{array}{l}\text { Sig. F } \\
\text { Change }\end{array}$ & \\
\hline 1 & $.513^{\mathrm{a}}$ & .263 & .257 & .80298 & .263 & 44.169 & 2 & 247 & .000 & \\
\hline 2 & $.547^{\mathrm{b}}$ & .299 & .288 & .78646 & .036 & 6.243 & 2 & 245 & .002 & \\
\hline 3 & $.765^{c}$ & .585 & .575 & .60763 & .286 & 83.716 & 2 & 243 & .000 & \\
\hline 4 & $.839^{d}$ & .704 & .694 & .51529 & .119 & 48.447 & 2 & 241 & .000 & \\
\hline 5 & $.843^{\mathrm{e}}$ & .710 & .698 & .51214 & .006 & 2.488 & 2 & 239 & .085 & \\
\hline 6 & $.849^{f}$ & .721 & .707 & .50408 & .011 & 4.854 & 2 & 237 & .009 & \\
\hline 7 & $.852^{\mathrm{g}}$ & .726 & .710 & .50178 & .005 & 2.085 & 2 & 235 & .127 & 2.051 \\
\hline
\end{tabular}


COMSATS Journal of Islamic Finance

\begin{tabular}{l}
\hline a. Predictors: (Constant), ModZRAFZMPF, RAF \\
\hline b. Predictors: (Constant), ModZRAFZMPF, RAF, EOUF, ModZEOUFZMPF \\
\hline c. Predictors: (Constant), ModZRAFZMPF, RAF, EOUF, ModZEOUFZMPF, CF, ModZCFZMPF \\
\hline d. Predictors: (Constant), ModZRAFZMPF, RAF, EOUF, ModZEOUFZMPF, CF, ModZCFZMPF, AF, ModZAFZMPF \\
\hline e. Predictors: (Constant), ModZRAFZMPF, RAF, EOUF, ModZEOUFZMPF, CF, ModZCFZMPF, AF, ModZAFZMPF, SIF, \\
ModZSIFZMPF \\
f. Predictors: (Constant), ModZRAFZMPF, RAF, EOUF, ModZEOUFZMPF, CF, ModZCFZMPF, AF, ModZAFZMPF, SIF, \\
ModZSIFZMPF, RIF, ModZRIFZMPF \\
g. Predictors: (Constant), ModZRAFZMPF, RAF, EOUF, ModZEOUFZMPF, CF, ModZCFZMPF, AF, ModZAFZMPF, SIF, \\
ModZSIFZMPF, RIF, ModZRIFZMPF, ModZGSFZMPF, GSF \\
\hline
\end{tabular}

Table 10 is of Model summary in which the value of $\mathrm{R}$ is 0.235 which moderate linear relationship between variables. The value of $\mathrm{R}$ square is 0.726 which shows $72.6 \%$ intension to use Islamic banking. As the value of Durbin-Watson 2.051 is close to 2 so there is no auto correlation. Further table of summary shows $\mathrm{R}$ square change because of all variables.

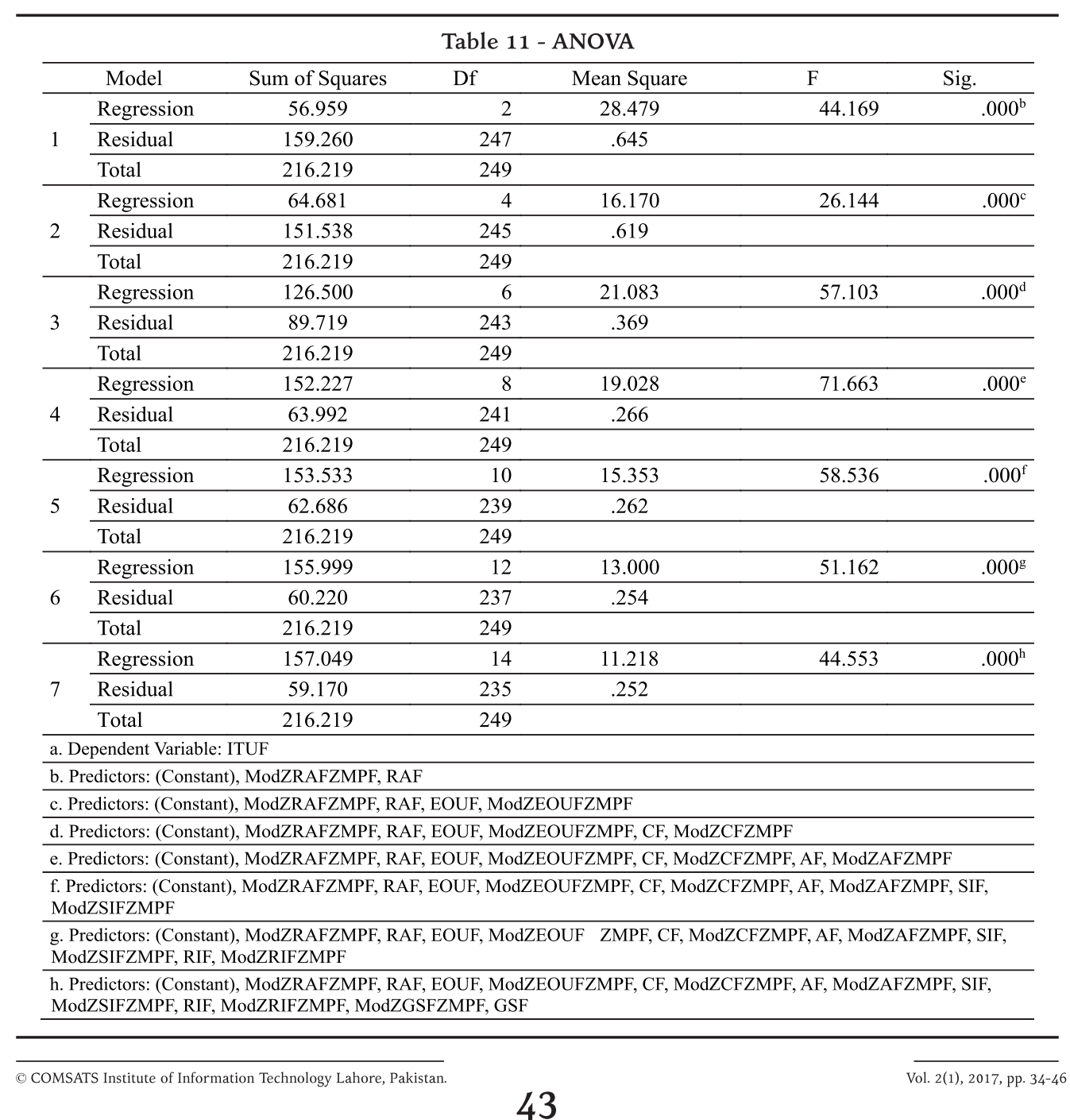


Afzal et al

ANOVA Table 11 shows significance of the model. The significance value is 0.000 in table which is less than significance level 0.005 . It shows model is fit and significant.

Table 12 - Coefficients

\begin{tabular}{|c|c|c|c|c|c|}
\hline \multirow[t]{2}{*}{ Model } & \multicolumn{2}{|c|}{ Unstandardized Coefficients } & \multirow{2}{*}{$\frac{\text { Standardized Coefficients }}{\text { Beta }}$} & \multirow[t]{2}{*}{$\mathrm{T}$} & \multirow[t]{2}{*}{ Sig. } \\
\hline & B & Std. Error & & & \\
\hline (Constant) & .037 & .153 & & .242 & .809 \\
\hline RAF & -.035 & .063 & -.028 & -.551 & .582 \\
\hline ModZRAFZMPF & .018 & .044 & .025 & .419 & .676 \\
\hline EOUF & .048 & .065 & .035 & .741 & .459 \\
\hline ModZEOUFZMPF & .003 & .041 & .003 & .065 & .948 \\
\hline $\mathrm{CF}$ & .214 & .065 & .205 & 3.269 & .001 \\
\hline ModZCFZMPF & -.037 & .060 & -.045 & -.624 & .533 \\
\hline $\mathrm{AF}$ & .516 & .069 & .501 & 7.513 & .000 \\
\hline ModZAFZMPF & -.042 & .059 & -.049 & -.703 & .483 \\
\hline SIF & .123 & .062 & .114 & 1.992 & .048 \\
\hline ModZSIFZMPF & -.010 & .048 & -.013 & -.214 & .831 \\
\hline RIF & .151 & .055 & .149 & 2.755 & .006 \\
\hline ModZRIFZMPF & .070 & .053 & .080 & 1.323 & .187 \\
\hline GSF & -.089 & .047 & -.076 & -1.885 & .061 \\
\hline ModZGSFZMPF & -.019 & .034 & -.021 & -.546 & .586 \\
\hline \multicolumn{6}{|c|}{ a. Dependent Variable: ITUF } \\
\hline
\end{tabular}

Table 12 is the table of coefficients which tells us which variables should we include in the model and which should not. As in this table the significance value of compatibility, attitude, social influence and religious influence is less than 0.05 so we can say that these variables are significant to predict intension to use Islamic banking. So from table 12 it is evident that there is the positive moderating effect of pricing on the relationship of compatibility, attitude, social influence, religious influence and intension to use Islamic banking.

\begin{tabular}{|l|l|c|}
\hline Hypothesis 5 & $\begin{array}{l}\text { Price plays a moderating role between attitude and intent to use Islamic } \\
\text { banking. }\end{array}$ & Accepted \\
\hline Hypothesis 6 & $\begin{array}{l}\text { Price plays a moderating role between social influence and the intent to } \\
\text { use Islamic Banking. }\end{array}$ & Accepted \\
\hline Hypothesis 7 & $\begin{array}{l}\text { Price plays a moderating role between religious influence and the intent } \\
\text { to use Islamic Banking. }\end{array}$ & Accepted \\
\hline Hypothesis 8 & $\begin{array}{l}\text { Price plays a moderating role between govenment support and the intent } \\
\text { to use Islamic Banking. }\end{array}$ & Rejected \\
\hline
\end{tabular}


9. Conclusion

This study was undertaken with an objective of studying the customer's intentions to use Islamic Banking. It attempted to find the factors that dictate decisions regarding opting of Islamic Banking among those residing in Lahore Pakistan. This study was carried out with the realization of the potential that Islamic banking has in attracting and appealing to the majority of the Pakistani population. The research findings suggest that attitude, compatibility, social influence accompanied by religious influence play a considerable role in inclination of prospective customers towards Islamic Banking. Further findings suggest that ease of use, relative advantage and government support do not have a considerable say in reaching decisions on whether to opt Islamic Banking or not. The study concludes the need of focusing on governing and utilizing factors like attitude, social influence, religious influence, government support and pricing for ensuring maximum coverage of Islamic Banking. Focus on these factors has the potential of ensuring greater financial inclusion by attracting even those who have reservations on the conventional banking system.

\section{Recommendations}

Overall Islamic Banking faces certain challenges that are existent because of financial and economic system of the countries where these are founded to mainly support the conventional style of banking. Considering the challenges following recommendations are suggested for future:

1. Primary focus should be given to creating awareness regarding the Islamic Banking as through this the general perception of Islamic Banking being similar to conventional banking can be removed.

2. The presence of Islamic Banking must be ensured throughout the country. This can be done by asking the Islamic Banks to open their branches in every locality.

3. It is a well-known fact that Islamic Banking industry follows KIBOR which is a benchmark of conventional banks and does not have its own Benchmark. Shariah Advisors must work to make their own benchmark which satisfies all the requirements given in Shariah and its obligation of Islam.

4. A detailed information of Islamic banking products and services can actually bring customers towards it and therefore it is recommended that rather than keeping it hidden from the prospective customers sincere efforts should be made to share this knowledge with the general public

5. Government of Pakistan must also express its full commitment in implementation of Islamic banking. This can be done by introducing suitable legislation and practical framework that harnesses the growth of Islamic Banking in the country.

6. Religious leaders including the scholars involved in Friday sermons must be brought on board so that they can create awareness and promote acceptance of Islamic Banking in their localities. Mosques can be a suitable platform that can facilitate Islamic banking survival and promotion in an excellent manner.

\section{Reference}

AhasanulHaq, Jamil.O and Ahmad .Z(2007) 'Islamic Banking: Customerperception and its prospect on bankproduct selection towards Malaysiancustomer perspectives', paper presented atthe Fifth International Islamic FinanceConference, 3-4th September, Kualalumpur.

Ajam, A., \& Nor, K. (2013). Internet Banking Adoption: Integrating Technology Acceptance Model and Trust. European Journal of Business and Management, 5(3), 207-215.

Al-Jarhi A. M., \& Iqbal, M. (2001). Islamic Banking: Answers to Some Frequently Asked Questions, Occasional paper No. 4 Islamic Development Bank, Islamic Research and Training Institute.

Amin, H., \& Rahim, A. (2009), Determinants of customers' intention to use Islamic personal financing. The case of Malaysian Islamic banks. Journal of Islamic Accounting and Business Research, 2(1), 22-42.

Amin, H., Rahim, A., Rahman, A., SondohJr, S. \& ChooiHwa, M. (2011), Determinants of customers intention to use Islamic personal financing: The case of Malaysian Islamic banks, Journal of Islamic Accounting and Business Research, 2 (1), $22-42$.

Aziz, Z. A. (2006). Islamic Banking and Finance Progress and Prospects: Collected Speeches 2000-2006. Bank Negara Malaysia, Kuala Lumpur.

Bonne, K., I. Vermeir, B.-B. Florence, and W. Verbeke, (2007) "Determinants of halal meat consumption in France," British Food Journal, vol. 109, pp. 367-386

Chapra, M. U. (2008). The global financial crisis: Can Islamic Finance helps minimize the severity and frequency of such a crisis in the future? Forum on the global financial crises. 
Gerard, P. and J.B. Cunningham, (2003). 'The diffusion of Internet Banking among Singapore Consumers', International Journal of Bank Marketing, 21(1), 16-28.

Gopi, M., and Ramayah, T. (2007). Applicability of theory of planned behaviour in predicting intention to trade online: some evidence from a developing country. International Journal of Emerging Markets, 2(4), 348- 360.

Hanudin, Abdul Rahim, Stephen L., \& Ang Magdalene (2011), Determinants of customer's intention to use Islamic personal financing: The case of Malaysian Islamic banks. Journal of Islamic Accounting and Business Research, 2(1), 22-42.

Iqbal, M., Ahmed, A., \& Khan, T. (1998). Challenges facing Islamic Banking, Islamic Research Training Institute, Occasional paper No.1, King Fahad National Library.

Jamshidi, D., \& Hussin, N. (2012). A conceptual framework for adoption of Islamic Credit Card in Malaysia. Kuwait Chapter of Arabian Journal of Business and Management Review, 2(3), 102-110.

Johnston, R. L. (1975). Religious and society in interaction: the sociology of religion. Englewood Cliffs, NJ: Prentice Hall.

Khan, H., \& Asghar, N. (2012). Customer awareness and adoption of Islamic Banking in Pakistan. Interdisciplinary Journal of Contemporary Research in Business, 3(9), 359-366.

Khurram, N., \& Saeed, U. (2015). Factors Influencing the Intention of People to Use Islamic Banking: Evidence from Lahore, Pakistan. International Journal of Economics and Empirical Research, 3(8), 411-418.

Metawa, S. A., \& Almossawi, M. (1998). Banking behavior of Islamic bank customers: perspectives and implications. International Journal of Bank Marketing, 16(7), $299-313$.

Mirakhor, A. (2000) 'General Characteristics of an Islamic Economic System', Anthology of Islamic Banking, Institute of Islamic Banking and Insurance, London, 11-31.

Najamabadi, M.H. (1991). Ta'seer-e Tahavolat-e Ban-kadri Jadeed dar Abzar-e Siasathay-e Pouli va Etabar (The impact of new banking reforms on monetary and credit policy tools)", First Seminar on Monetary and Foreign Exchange Policies, Tehran, Iran.

Nasri, W. (2011). Factors Influencing the Adoption of Internet Banking in Tunisia. International Journal of Business and Management, 6(8), 143-160.

Olson, D. and Zoubi, T., (2008,) Using Accounting Ratios to distinguish between Islamic and Conventional Banks in the GCC Region, The International Journal of Accounting, 43, 45-6.

Ouafy, S., \&Chakir, A. (2015). The Impact of Religiosity in Explanation of Moroccan Very Small Businesses Behaviour Toward islamic Financial Products. IOSR Journal of Business and Management (IOSR-JBM), 17(7), 71-76.

Rogers, E.M. (2003). Diffusion of innovations (5th Ed.). New York: Free Press.

Schiffman and Kanuk (2004), Consumer Behavior, Prentice Hall, 2004, p. 250-287.

Stiglitz, J. (2003), Dealing with Debt: How to Reform the Global Financial System, Harvard International Review, 54-59.

Taib, F. M., Ramayah, T. \& Razak, D.A. (2008). Factor influencing intention to use diminishing partnership home financing. International Journal of Islamic and Middle Eastern Finance and Management, 1(3), 235- 48.

Tan, M., \& Teo, T.S.H. (2000). Factors influencing the adoption of Internet banking. Journal of the Association for information Systems, $1(5), 1-42$.

Tara, N., Irshad, M., Khan, M., \& Yamin, M. (2014). Factors Influencing Adoption of Islamic Banking: A Study from Pakistan. Journal of Public Administration and Governance, 4(3), 352-367.

Thambiah, S., Ismail, H. and Eze, U. C. (2010). Customer Awareness and Current Usage of Islamic Retail Banking Products and Services in Malaysia, Australian Journal of Basicand Applied Sciences, 5, 667-671.

Xihao, He and Jiaqin Yang. (2004). Social Influence on Consumers' Purchasing Behavior and Related Marketing Strategy A Cross Nation Comparative Study. 